\title{
Effect of population density and nitrogen fertilizer levels on growth, yield components, yield, and fiber properties of Egyptian cotton (Giza 95)
}

\author{
Melad A. S. Ghoprial ${ }^{1}$; Sedhom A. Sedhom ${ }^{2}$; Sadiek A. S. Mohasen ${ }^{2}$; Fekry S. Hamed ${ }^{1}$ \\ and El-Saeed M. M. El-Gedwy ${ }^{2}$ \\ ${ }^{1}$ Cotton Research Institute, Agricultural Research Center, Giza, Egypt. \\ ${ }^{2}$ Agronomy Department, Faculty of Agriculture, Benha University, Egypt. \\ Corresponding author: medovenus202020@gmail.com
}

\begin{abstract}
Two field experiments were carried out at the Farm of Sids Research Station, BaniSwef Governorate, Agricultural Research Center, Egypt, during the two successive seasons of 2016 and 2017. The aim of this study was to investigate the effect of three population density through five plant distribution, i.e. 64615 plants/fed from $10 \mathrm{~cm}$ between hills with leaving single plant/hill (A), 64615 plants/fed from $20 \mathrm{~cm}$ between hills with leaving double plants/hill (B), 43076 plants/fed from $15 \mathrm{~cm}$ between hills with leaving single plant/hill (c), 43076 plants/fed from $30 \mathrm{~cm}$ between hills with leaving double plants/hill (D) and 51692 plants/fed from $25 \mathrm{~cm}$ between hills with leaving double plants/hill (E) under four nitrogen fertilizer levels, i.e. (30, 45, 60 and $75 \mathrm{Kg}$ $\mathrm{N} / \mathrm{fed}$ ) on growth, flowering, yield components and yield as well as fiber quality properties for the Egyptian cotton (Gossypium barbadense, L.), variety Giza 95.

Significant differences were detected for allmost growth, flowers, yield components and yield as well as fiber properties of cotton among the three plant densities through five plant distributions or four nitrogen fertilizer levels during 2016 and 2017 seasons. Planting pattern of D significantly surpassed the other plant densities and distributions and gave the greatest values in No. of sympodia/plant, No. of fruiting sites/plant, No. of open bolls/plant, boll weight, seed index, seed cotton yield/plant, upper half mean length and uniformity index $\%$ as well as significantly gave the shortest period from planting to first flower appearance and lowest values of plant losses \% at harvest. Meanwhile, planting pattern of E significantly gave the highest values of seed and lint cotton yields/fed. On the other hand, the greatest values of plant height, No. of days to first flower appearance, lint \% and plant losses $\%$ were obtained from planting pattern of A. While, planting pattern of B gave the lowest values of micronaire reading. While, the maximum values of strength $(\mathrm{g} / \mathrm{tex})$ was recorded from planting pattern of $\mathrm{C}$. plant height, No. of sympodia/plant, No. of days to first flower appearance, No. of fruiting sites/plant, No. of open bolls/plant, boll weight, seed index, seed cotton yield/plant, seed cotton yield/fed, lint cotton yield/fed and uniformity index \% showed significantly increased by increasing nitrogen fertilizer levels from 30 up to $75 \mathrm{~kg}$ $\mathrm{N} / \mathrm{fad}$, except lint $\%$ and micronaire reading were significantly decreased in the both seasons. Results revealed that planting pattern of $\mathrm{D}$ under soil fertilized by $75 \mathrm{~kg} \mathrm{~N} / \mathrm{fed}$ gave the maximum values of No. of sympodia/plant, No. of fruiting sites/plant, No. of open bolls/plant, boll weight and seed cotton yield/plant. While, planting pattern of $\mathrm{E}$ with the same level of nitrogen produced the maximum values of seed and lint cotton yields/fed. Meanwhile, the greatest values of plant height and the longest period from planting to first flower appearance were obtained from planting pattern of $\mathrm{A}$ when received $75 \mathrm{~kg} \mathrm{~N} /$ fed during both growing seasons. It could be summarized that planting cotton plants (Giza 95) under planting patterns of D or E with soil fertilized by $75 \mathrm{~kg} \mathrm{~N} /$ fad to maximized quantity and quality of cotton yield characters.
\end{abstract}

Keywords: Egyptian cotton, plant population density, nitrogen fertilizer level, fiber properties

\section{Introduction}

Cotton (Gossypium barbadense L.) is considered the main fiber crop in Egypt as well as the world. Therefore, a great effort should be continued to improve its quality and quantity either through cultural practices and breeding programs. The cotton yield or any other economic character, is influenced by the various agronomic practices especially the amount of fertilizers or plant density. Therefore, the important question is, what is the most suitable amount of nitrogen fertilizer, how many plants per fed are needed with suitable distribution for these plants in the field to obtain the maximum yield with high quality. The cultivated area of cotton is going lower year by year, in spite of its importance for national economy, textile industry, food oil and animal feed production and also its role in increasing and maintenance of soil fertility. Egyptian statistics indicates decreasing of cotton cultivated area from 851283 fed on 1991 year to about 216554 fed on 2017 year, with decreasing percent of about $74.56 \%$ that lead to a decrease in cotton production from 5826000 kentars on 1991 year to about 1357000 kentars on 2017 year, with decreasing percent by about $76.71 \%$ in 2017 year comparing with the year 1991. (Egyptian Cotton Gazette, 2017). One of the lowest cotton cultivated area, due to unfair prices to producers and better net profits from alternatives crops especially grains, in the same time costs of 
cotton inputs. In addition the very high cost of hand picking and insufficient trained picking workers. The decrease of cotton production in recent years has a negative reflection on local and international market supply.

Population density in cotton is aimed to find the desirable number of plants/fed and the suitable distribution for these plants in order to decrease competition between plants within hills on environmental requirements and produce higher yields and good quality. Khan et al., (2001), ElSayed and El-Menshawi (2005), Ali et al., (2011), Alitabar et al., (2012), Hamed et al., (2012), Deshish (2013), Abd El-Aal (2014), Deshish et al., (2015), Munir et al., (2015), Alubaidi et al., (2016), Khan et al., (2017), Madavi et al., (2017), Mccarty et al., (2017), Nagender et al., (2017), Shah et al., (2017) and Panhwar et al., (2018) found that decreasing cotton population density showed significant increases in No. of sympodia branches/plant, No. of open bolls/plant, seed cotton yield/fed unit area and lint cotton yield/unit area, while plant height was significantly decreased. Siddiqui et al., (2007), Darawsheh et al., (2009), Hamed et al., (2012), Deshish (2013), Abd El-Aal (2014), Khan et al., (2017), Madavi et al., (2017), Mccarty et al., (2017), Nagender et al., (2017) and Panhwar et al., (2018) revealed that No. of days to first flower appearance, lint $\%$ and plant losses $\%$ at harvest increased significantly as population density was increased. Ali et al., (2009), Nadeem et al., (2010), El-Shahawy and Hamoda (2011), Hamoda et al., (2014), Munir et al., (2015), Alubaidi et al., (2016), Khan et al., (2017), Madavi et al., (2017), Mccarty et al., (2017), Nagender et al., (2017), Shah et al., (2017) and Panhwar et al., (2018) noticed that seed index, boll weight and seed cotton yield/plant significantly decreased by increased population density. Hamed et al., (2012) and Panhwar et al., (2018) stated that decreasing population density led to increase No. of fruiting sites/plant. Darawsheh et al., (2009) and Panhwar et al., (2018) found that boll weight, 100-seed weight, $2.5 \%$ span length, uniformity ratio \% and strength (g/tex) were significantly decreased by increasing plant density from 32 to 16 cotton plants $/ \mathrm{m}^{2}$. On the other hand, lint $\%$ and micronaire reading were significantly increased.

Nitrogen is an important factor limiting plant growth. The response of cotton plants to nitrogen fertilization depends mainly on soil fertility level and cotton variety. Therefore, it is suitable to apply nitrogen fertilizer in an adequate amount necessary for plant nutrition to produce higher yields with good quality. Hamed et al., (2012), Alubaidi et al., (2016), Nagender et al., (2017), Mubarak and Janat (2018) and Panhwar et al., (2018) found that No. of fruiting sites/plant and lint cotton yield/unit area were significantly increased by increasing levels of nitrogen fertilizers, while lint \% was significantly decreased. Khan et al., (2001), El-Sayed and ElMenshawi (2005), Nadeem et al., (2010), Ali et al., (2011), El-Shahawy and Hamoda (2011), Alitabar et al., (2012), Hamed et al., (2012), Hamed, F. S. (13), Deshish (2013), Abd El-Aal (2014), Hamoda et al., (2014), Munir et al., (2015), Alubaidi et al., (2016), Nagender et al., (2017), Mubarak and Janat (2018) and Panhwar et al., (2018) clear that increasing nitrogen fertilizer levels significantly increased plant height, number of sympodia branches/plant, No. of days to first flower appearance, No. of fruiting sites/plant, No. of open bolls/plant, boll weight, seed index, seed cotton yield/plant, seed cotton yield/unit area and lint cotton yield/unit area. Deshish (2013), Madani and Oveysi (2015), Ran et al., (2015) and Panhwar et al., (2018) indicated that upper half mean length, length uniformity index, fiber strength, and micronaire values were significantly improved with increasing nitrogen fertilizer levels.

The significant interaction between population density and nitrogen fertilizer levels was showed on some cotton characters, i.e. plant height, No. of sympodia/plant, No. of days to first flower appearance, No. of fruiting sites/plant, No. of open bolls/plant, boll weight, seed index, lint $\%$, seed cotton yield/plant, seed cotton yield/unit area, lint cotton yield/unit area and strength (g/tex) El-Sayed and El-Menshawi (2005), Nadeem et al., (2010), Ali et al., (2011), El-Shahawy and Hamoda (2011), Alitabar et al., (2012), Hamed et al., (2012), Deshish (2013), Abd El-Aal (2014), Hamoda et al., (2014), Munir et al., (2015), Alubaidi et al., (2016), Nagender et al., (2017), Singh et al., (2017) and Panhwar et al., (2018).

The aim of this study was to investigate the suitable agricultural managements practices such as, planting patterns (hill spacing and No. of plants/hill) and nitrogen fertilizer levels of new promising variety cotton Giza 95.

\section{Materials and Methods}

Two field experiments were carried out at the Farm of Sids Research Station, BaniSwef Governorate, Agricultural Research Center, Egypt, during the two successive seasons of 2016 and 2017. The aim of this study was to investigate the effect of three population density through five plant distribution and nitrogen fertilizer levels on growth, flowering, yield components, yield and fiber quality properties for the Egyptian cotton (Gossypium barbadense L.), variety Giza 95 . It is classified as a long staple variety grown in Middle Egypt, which was developed from a cross between (Giza 83 X Giza $80 \mathrm{X}$ 5844) and Giza 80. Soil texture of the experimental site was silty clay loam. The chemical and mechanical properties analysis of the experimental soil were determined according to the standard procedures described by Black and Evans 
(1965) and represented in Table 1 in each of the two growing seasons.

For each season, the field experiment included twenty treatments represented the combination between three population densities with five plant distribution treatments and four nitrogen fertilizer levels.

Table 1. Chemical and mechanical properties analysis of the experimental soil units of the two growing seasons (2016 and 2017).

\begin{tabular}{|c|c|c|c|}
\hline & & 2016 season & 2017 season \\
\hline \multirow{3}{*}{ Chemical analysis } & Sand\% & $20 \%$ & $18 \%$ \\
\hline & Silt & $50 \%$ & $52 \%$ \\
\hline & Clay & $30 \%$ & $30 \%$ \\
\hline Soil texture & \multicolumn{3}{|c|}{ Silty clay loam } \\
\hline \multirow{10}{*}{ Chemical analysis } & $\mathbf{P H}$ & 8.2 & 7.7 \\
\hline & $\mathrm{CaCo3} \%$ & 2.7 & 2.9 \\
\hline & E.C (mmohs) /cm & 0.57 & 0.43 \\
\hline & Available N(ppm) & 26.0 & 22.0 \\
\hline & Available P(ppm) & 15.8 & $\mathbf{1 7 . 2}$ \\
\hline & Available K(ppm) & 283 & 294 \\
\hline & Available Fe(ppm) & 9.9 & 11.2 \\
\hline & Available Mn(ppm) & 12.2 & 10.3 \\
\hline & Available Zn(ppm) & 1.4 & 1.5 \\
\hline & Available Cu(ppm) & 3.4 & 3.7 \\
\hline
\end{tabular}

Factors under study were as follows:

A- Three population densities through five plant distribution treatments:-

1. 64615 plants/fed from $10 \mathrm{~cm}$ between hills with leaving single plant/hill (A).

2. 64615 plants/fed from $20 \mathrm{~cm}$ between hills with leaving double plants/hill (B).

3. 43076 plants/fed from $15 \mathrm{~cm}$ between hills with leaving single plant/hill (C).

4. 43076 plants/fed from $30 \mathrm{~cm}$ between hills with leaving double plants/hill (D).

5. 51692 plants/fed from $25 \mathrm{~cm}$ between hills with leaving double plants/hill (E).

Cotton planting was done by the local method of dibbling 5 to 7 seeds in each hill by hand and thinned after about 35 days from planting dare, leaving the required number of plants/hill.

B- Four nitrogen fertilization levels: 30, 45, 60 and $75 \mathrm{~kg} \mathrm{~N} / \mathrm{fed}$.

Nitrogen fertilizer was applied in form of ammonium nitrate $(33 \% \mathrm{~N})$, and divided into two equal parts and applied side dressed before the first and second irrigations in each season.

Experiments were planted on $15^{\text {th }}$ and $24^{\text {th }}$ of March in the first and the second seasons, respectively. The preceding summer crop was grain sorghum then Egyptian clover as a catch crop in winter season in the two seasons. The experimental design was split plot design in four replications. Each of the three population densities through five plant distribution treatments were distributed in the main plots, whereas the four nitrogen fertilizer levels were arranged at random in sub plots. The sub plot area was $13.65 \mathrm{~m}^{2}$ and contained seven ridges of $3 \mathrm{~m}$ long and $65 \mathrm{~cm}$ apart. Phosphorous fertilizer was applied in form of Calcium super phosphate $\left(15.5 \% \mathrm{P}_{2} \mathrm{O}_{5}\right)$ at a level of $150 \mathrm{~kg} / \mathrm{fed}$ after ridging and before planting in each season. Potassium fertilizer was applied in form of potassium sulphate $\left(48 \% \mathrm{~K}_{2} \mathrm{O}\right)$ at a level of $50 \mathrm{~kg} / \mathrm{fed}$ in one dose before the second irrigation in each season. All recommended cultural practices for growing cotton according to the Farm of Sids Research Station, BaniSwef Governorate, Agricultural Research Center recommendation were done properly.

\section{Characters studied:}

Ten guarded cotton plants were taken randomly from each sub-plot to determine.

1) Plant height $(\mathrm{cm})$. The plant height was measured in $\mathrm{cm}$, from the cotyledonary node to the top of the plant at harvest and average was computed.

2) Number of sympodia/plant at harvest.

3) Number of days to first flower appearance. It was determined as the number of days from planting until the appearance of first flower.

4) Number of fruiting sites/plant. Since flower counts were taken daily during the flowering season, it was possible to calculate the total No. of fruiting sites produced/plant.

5) Number of open bolls/plant. It was calculated by counting the open bolls/plant on the above the representative plants before the first and second picking.

6) Boll weight (g). It was calculated from the following formula:

Boll weight $(g)=\quad$ Seed cotton yield $/$ plant $(g)$ Number of open bolls/plant at harvest 
7) Seed index (g). It was estimated from the average of 100 -seed weight $(\mathrm{g})$ was taken at random after ginning.

8) Lint percentage. It was calculated from the following equation:

$$
\text { Lint percentage }=\frac{\text { Lint cotton yield/plant }(g)}{\text { Seed cotton yield/plant }(g)} \times 100 .
$$

9) Plant losses $\%$ at harvest. It was calculated from the following equation:

$$
\text { Plant losses } \%=\left\{1-\left(\frac{\text { Number of plant/f ed at harvest }}{\text { Original number of plant/f ed }}\right)\right\} \mathbf{x} 100 .
$$

10) Seed cotton yield/plant (g). It was estimate from the above ten representative plants.

11) Seed cotton yield/fed (kentar): It was estimated and transformed to kentar/fed (one kentar $=157.5$ $\mathrm{kg}$ ), the seed cotton yield was picked twice in the two seasons, in picking from whole plants of plot were selected to be picked in order to avoid border effect.

12) Lint cotton yield/fed (kentar): It was estimated and transformed to kentar/fed (one kentar $=50$ $\mathrm{kg}$ ), it was calculated from the following equation:

Lint cotton yield $/$ fed $($ kentar $)=\frac{\text { Seed cotton yield } / \text { fed }(\text { kentar }) \times 157.5 \times \text { Lint } \%}{50 \times 100}$.

\section{Fiber properties:}

The measurement of some fiber technological properties were determined at Cotton Technology Research Division, Cotton Research Institute, Giza, Egypt, at a constant relative humidity $65 \%( \pm 2)$ and temperature $21 \mathrm{C}^{\mathrm{O}}( \pm 2)$ by using High Volume Instrument (HVI) according to (A.S.T.M., 1986), for the following traits.

13) Upper half mean length $(\mathrm{mm})(2.5 \%$ span length).

14) Length uniformity ratio. It was calculated from the following equation:

$$
\text { Length unif ormity ratio }=\frac{50 \% \text { span length }(\mathrm{mm})}{2.5 \% \text { span length }(\mathrm{mm})} \times \mathbf{1 0 0} .
$$

15) Fiber strength ( $g /$ tex $)$.

16) Fiber elongation percentage.

17) Micronaire reading (Mic. Reading).

\section{Statistical analysis:}

The analysis of variance was carried out according to the procedure described by Gomez and Gomez (1984). Data were statistically analyzed according to using the MSTAT-C Statistical Software Package (Michigan State University, 1983). Where the F-test showed significant differences among means L. S. D. test at 0.05 level was used to compare between means.

\section{Results and Discussion}

\section{A- Effect of population density through plant distributions:}

Results presented in Tables 2, 3, 4 and 5 revealed that the differences between the studied three population density through five plant distribution, i.e. 64615 plants/fed from $10 \mathrm{~cm}$ between hills with leaving single plant/hill (A), 64615 plants/fed from
$20 \mathrm{~cm}$ between hills with leaving double plants/hill (B), 43076 plants/fed from $15 \mathrm{~cm}$ between hills with leaving single plant/hill (c), 43076 plants/fed from 30 $\mathrm{cm}$ between hills with leaving double plants/hill (D) and 51692 plants/fed from $25 \mathrm{~cm}$ between hills with leaving double plants/hill (E) on growth, flowering, yield components, yield and fiber quality properties for the Egyptian cotton variety Giza 95 in the both seasons were significant except, upper half mean length in the first season and elongation $\%$ in both season were not significant.

Results revealed that planting pattern of D gave the greatest mean values of No. of sympodia/plant (19.18 and 20.25 branches), No. of fruiting sites/plant (36.23 and 39.10 fruiting sites), No. of open bolls/plant (14.13 and 14.68 bolls), boll weight (2.588 and $2.503 \mathrm{~g}$ ), seed index (8.718 and $8.950 \mathrm{~g}$ ), seed cotton yield/plant (36.69 and $36.76 \mathrm{~g}$ ), upper half mean length (30.72 and $31.04 \mathrm{~mm})$ and uniformity index (83.97 and 83.89) as well as significantly gave the shortest period from planting to first flower appearance (68.38 and 69.00 days) and lowest values of plant losses percentage (3.44 and $2.90 \%$ ) in the first and second seasons, respectively. This trend could be explained on the fact that in case of low population density produced by increasing hill spacing resulted in low competition between it for nutrient elements, soil moisture and sun light, plants would have better opportunity to produce more metabolite contents and positive effect on plant growth and productivity as well as increased translocation and consequently accumulation of metabolites through fruits and gave the maximum values of plant traits and yield components. Similar findings were obtained by Khan et al., (2001), ElSayed and El-Menshawi (2005), Ali et al., (2011), Alitabar et al., (2012), Hamed et al., (2012), Deshish (2013), Abd El-Aal (2014), Deshish et al., (2015), Munir et al., (2015), Alubaidi et al., (2016), Khan et al., (2017), Madavi et al., (2017), Mccarty et al., (2017), Nagender et al., (2017), Shah et al., (2017) and Panhwar et al., (2018).

Data may reveal the superiority of planting pattern of $E$ in seed cotton yield/fed (9.753 and 9.630 kentars) and lint cotton yield/fed (11.815 and 9.630 kentars) in the first and second seasons, respectively, but, there was no significant difference between planting patterns of $\mathrm{D}$ and $\mathrm{E}$ on seed and lint cotton yields/fed. This result may be due to the increase in number of open bolls/plant, boll weight $(\mathrm{g})$, seed cotton yield/plant $(\mathrm{g})$ and number of plants/fed at harvest. Many investigators obtained similar results as Alubaidi et al., (2016), Mccarty et al., (2017), Nagender et al., (2017), Shah et al., (2017) and Panhwar et al., (2018).

The greatest values of plant height (134.03 and $140.65 \mathrm{~cm})$, No. of days to first flower appearance (73.25 and 75.00 days), lint percentage (39.70 and $70.76 \%)$ and plant losses percentage (7.08 and 5.86 $\%)$ in the first and second seasons, respectively were 
obtained from planting pattern of $\mathrm{A}$ as well as significantly gave the minimum values in allmost studies traits under study. The increases in plant height by increasing plant densities is mainly due to the increased intra-specific competition among cotton plants for light and decrease in light penetration, interception and photosynthetic efficiency at higher densities as well as higher dense of plants excessive shade exist which help to produce more content of gibberellin in tissues and consequently higher plants formed. These results are in harmony with those reported by Khan et al., (2001), El-Sayed and ElMenshawi (2005), Siddiqui et al., (2007), Darawsheh et al., (2009), Ali et al., (2011), Alitabar et al., (2012), Hamed et al., (2012), Deshish (2013), Abd El-Aal (2014), Deshish et al., (2015), Munir et al., (2015), Alubaidi et al., (2016), Khan et al., (2017), Madavi et al., (2017), Mccarty et al., (2017), Nagender et al., (2017), Shah et al., (2017) and Panhwar et al., (2018).

Planting pattern of $\mathrm{B}$ gave the lowest values of micronaire reading or highest values of fiber fineness (3.702 and 3.739) in the both season, respectively. While, the maximum values of strength (38.95 and $37.90 \mathrm{~g} /$ tex $)$ and micronaire reading or fiber maturity (3.888 and 3.895) in the first and second seasons, respectively) were recorded from planting pattern of C. These results are in harmony with those reported by Darawsheh et al., (2009) and Panhwar et al., (2018).

\section{B- Effect of nitrogen fertilizer levels:}

Results in Tables 2, 3, 4 and 5 showed that growth, flowering, yield components, yield and fiber quality properties for the Egyptian cotton variety Giza 95, i.e. plant height, No. of sympodia/plant, No. of days to first flower appearance, No. of fruiting sites/plant, No. of open bolls/plant, boll weight, seed index, seed cotton yield/plant, seed cotton yield/fed, lint cotton yield/fed and uniformity index \% were significantly increased by increasing nitrogen fertilizer levels from 30 to $75 \mathrm{~kg} \mathrm{~N} /$ fed in $1^{\text {st }}$ and $2^{\text {nd }}$ seasons. On the other hand, lint $\%$ and micronaire reading (fiber maturity) were decreased with increasing nitrogen levels in the both seasons. Meanwhile, mean values of plant losses \%, upper half mean length, strength and elongation $\%$ were not significantly affected by increasing nitrogen fertilizer levels during the both seasons. Results reported that no significant differences between soil fertilized by 60 and $75 \mathrm{~kg} \mathrm{~N} / \mathrm{fad}$ on allmost cotton traits under study.

In general, the higher nitrogen level ( $75 \mathrm{~kg} \mathrm{~N} / \mathrm{fed})$ was more effective in increasing mean values of all studied traits, also, produced the maximum seed and lint cotton yields/fed and proved significantly superior to other nitrogen levels. These results revealed that planting cotton under soil fertilized by $75 \mathrm{~kg} \mathrm{~N} /$ fed gave the greatest mean values of plant height $(132.62$ and $138.62 \mathrm{~cm})$, No. of sympodia/plant (19.32 and 20.52 branches), No. of days to first flower appearance (72.40 and 73.30 days), No. of fruiting sites/plant (31.50 and 32.74 fruiting sites), No. of open bolls/plant (12.42 and 12.70 bolls), boll weight ( 2.456 and $2.406 \mathrm{~g}$ ), seed index (8.718 and $9.028 \mathrm{~g}$ ), seed cotton yield/plant (30.89 and $30.85 \mathrm{~g})$, seed cotton yield/fed (9.664 and 9.428 kentars), lint cotton yield/fed (11.688 and 11.372 kentars) and uniformity index (83.46 and $83.53 \%)$ as well as significantly gave the lowest percentage of lint (38.46 and $38.39 \%)$ and micronaire reading (3.670 and 3.712) in the first and second seasons, respectively. The superiority rations in the first season between the highest nitrogen level $(75 \mathrm{~kg}$ $\mathrm{N} / \mathrm{fad}$ ) and each of 60,45 and $30 \mathrm{~kg} \mathrm{~N} /$ fad were 1.41 , 3.51 and $7.04 \%$ for plant height; $3.87,8.42,16.95 \%$ for No. of sympodia/plant; 0.80, 2.20 and 3.90 days for No. of days to first flower appearance; 4.86, 13.64, $29.52 \%$ for No. of fruiting sites/plant; 1.31, $6.15,23.21 \%$ for No. of open bolls/plant; 1.82, 4.42, $8.67 \%$ for boll weight; $1.51,4.26$ and $14.80 \%$ for seed index; 3.00, 10.92 and $33.90 \%$ for seed cotton yield/plant; 4.39, 16.52 and $44.89 \%$ for seed cotton yield/fed; 4.13, 15.40 and $41.71 \%$ for lint cotton yield/fed in addition to $0.40,1.08$ and $1.91 \%$ for uniformity index, respectively. The increases rations in the second season when cotton received $75 \mathrm{~kg}$ $\mathrm{N} /$ fad over each of 60,45 and $30 \mathrm{~kg} \mathrm{~N} /$ fad were 1.12 , $2.97 \%$ for plant height; $3.85,8.23$ and $14.51 \%$ for No. of sympodia/plant; $0.80,1.85$ and 3.75 days for No. of days to first flower appearance; 2.76, 9.06 and $23.45 \%$ for No. of fruiting sites/plant; 0.95, 3.76 and $12.79 \%$ for No. of open bolls/plant; 1.69, 2.82 and $11.49 \%$ for boll weight; $1.74,5.57$ and $13.96 \%$ for seed index; 2.56, 6.53 and $25.00 \%$ for seed cotton yield/plant; 2.34, 10.32 and $33.77 \%$ for seed cotton yield/fed; 1.01, 8.24 and $27.75 \%$ for lint cotton yield/fed in addition to $0.32,1.17$ and $1.86 \%$ for uniformity index, respectively.

The present results clearly indicate that nitrogen application induced increases in growth, flowering, yield components and yield traits of cotton showing the major role of this vital nutritive element. The increase in nitrogen application encourages photosynthesis activities and the metabolic efficiency as well as promoting the cell division, vegetative growth and encouraging the juvenility and active persistence of meristimatic tissues which contributes in enhancing the accumulation of the produced metabolites of cotton as well as increased plant height, number of fruiting branches/plant and No. of days to first flower appearance, No. of fruiting sites/plant, total No. of bolls/plant, No. of open bolls/plant, boll weight and seed index caused increases in seed cotton yield/plant, seed cotton yield/fed and lint cotton yield/fed. Many investigators came out with similar results as Khan et al., (2001), El-Sayed and El-Menshawi (2005), Nadeem et al., (2010), Ali et al., (2011), El-Shahawy and Hamoda (2011), Alitabar et al., (2012), Hamed et al., (2012), 
Hamed, F. S. (13), Deshish (2013), Abd El-Aal (2014), Hamoda et al., (2014), Madani and Oveysi (2015), Munir et al., (2015), Ran et al., (2015), Alubaidi et al., (2016), Nagender et al., (2017), Mubarak and Janat (2018) and Panhwar et al., (2018).

\section{C- Interaction effect}

Significant effect of the interaction between three population density through five plant distribution and nitrogen fertilizer levels obtained for almost growth, flowering, yield components and yield of cotton namely, plant height, No. of sympodia/plant, No. of days to first flower appearance, No. of fruiting sites/plant, No. of open bolls/plant, boll weight, seed cotton yield/plant, seed cotton yield/fed and lint cotton yield/fed. Meanwhile, mean values of seed index, lint $\%$, plant losses $\%$ and all fiber properties, i.e. upper half mean length, uniformity index, strength, elongation $\%$ and micronaire reading were not significantly affected by the interaction between plant population densities through plant distributions and nitrogen fertilizer levels during 2016 and 2017 seasons (Tables 2, 3, 4 and 5).

The results in Tables 2, 3 and 4 noticed that sowing cotton plants at a population density of $\mathrm{D}$ gave the highest mean values of No. of sympodia/plant, No. of fruiting sites/plant, No. of open bolls/plant, boll weight and seed cotton yield/plant in the first and second seasons under all nitrogen fertilizer levels, while population density of A recorded the lowest mean values under all nitrogen levels in both growing seasons. Similar trend was observed for other population densities in both growing seasons. Also, the highest nitrogen fertilizer level $(75 \mathrm{~kg} \mathrm{~N} / \mathrm{fed})$ gave the highest interaction values for these traits under all population densities in both growing seasons. Data revealed that planting pattern of D which fertilized by $75 \mathrm{~kg} \mathrm{~N} /$ fed recorded significantly the maximum values of No. of sympodia/plant (20.30 and 21.60 branches), No. of fruiting sites/plant (39.30 and 41.80 fruiting sites), No. of open bolls/plant (15.20 and 15.30 bolls), boll weight $(2.710$ and $2.550 \mathrm{~g})$, seed cotton yield/plant (41.19 and $39.02 \mathrm{~g}$ ) in the first and second seasons, respectively. Similar results were also reported by ElSayed and El-Menshawi (2005), Ali et al., (2011), Hamed et al., (2012), Deshish (2013), Abd El-Aal (2014), Hamoda et al., (2014), Alubaidi et al., (2016), Singh et al., (2017) and Panhwar et al., (2018).
The results in Tables 2, 3 and 4 revealed that sowing cotton plants at a population density of $\mathrm{E}$ gave the greatest mean values of seed cotton yield/fed and lint cotton yield/fed in the $1^{\text {st }}$ and $2^{\text {nd }}$ seasons under all nitrogen fertilizer levels, while population density of $\mathrm{A}$ recorded the lowest mean values under all nitrogen levels in both growing seasons. Similar trend was observed for other population densities in both growing seasons. Also, the highest nitrogen fertilizer level $(75 \mathrm{~kg} \mathrm{~N} / \mathrm{fed})$ gave the highest interaction values for these traits under all population densities in both growing seasons. Results indicated that planting pattern of $\mathrm{E}$ under the same nitrogen fertilizer level gave the greatest values of seed cotton yield/fed (11.080 and 10.430 kentars) and lint cotton yield/fed (13.310 and 12.380 kentars) in the first and second seasons, respectively. Similar results were also reported by Nadeem et al., (2010), El-Shahawy and Hamoda (2011), Alitabar et al., (2012), Hamed et al., (2012), Alubaidi et al., (2016), Singh et al., (2017) and Panhwar et al., (2018).

The greatest values of plant height (138.60 and $144.80 \mathrm{~cm}$ ) and the longest period from planting to first flower appearance (75.00 and 76.75 days) were obtained from planting pattern of A when received 75 $\mathrm{kg} \mathrm{N} / \mathrm{fed}$. Results indicated that planting cotton at a population density of A expressed the highest mean values for these traits with all nitrogen fertilizer levels, whereas, the population density of $\mathrm{D}$ gave the lowest values under all nitrogen levels in both growing seasons. The same trend was observed for other population densities in both seasons. Also, the highest nitrogen fertilizer level $(75 \mathrm{~kg} \mathrm{~N} / \mathrm{fed})$ gave the highest interaction values for these traits under all population densities in both growing seasons. Similar results were also reported by Hamed et al., (2012), Deshish (2013), Abd El-Aal (2014), Hamoda et al., (2014), Singh et al., (2017) and Panhwar et al., (2018).

\section{Conclusion}

It could be summarized that planting cotton plants (Giza 95) under planting population density of 51692 plants/fed from $25 \mathrm{~cm}$ between hills or 43076 plants/fed from $30 \mathrm{~cm}$ between hills with leaving double plants/hill and soil fertilized by $75 \mathrm{~kg} \mathrm{~N} /$ fad to maximized quantity and quality of cotton yield characters. 
Table 2. Effect of population densities through plant distributions, nitrogen fertilizer levels and their interaction on plant height, No. of sympodia/plant, No. of days to first boll appearance and No. of fruiting sites/plant of cotton during 2016 and 2017 seasons.

\begin{tabular}{|c|c|c|c|c|c|c|c|c|c|c|}
\hline \multirow{2}{*}{ Treatment } & \multirow{2}{*}{\multicolumn{2}{|c|}{$\begin{array}{c}\text { Trait } \\
\text { Season }\end{array}$}} & \multicolumn{2}{|c|}{$\begin{array}{c}\text { Plant height } \\
(\mathrm{cm})\end{array}$} & \multicolumn{2}{|c|}{$\begin{array}{c}\text { No. of } \\
\text { sympodia/plant }\end{array}$} & \multicolumn{2}{|c|}{$\begin{array}{c}\text { Days to first flower } \\
\text { appearance }\end{array}$} & \multicolumn{2}{|c|}{$\begin{array}{c}\text { No. of fruiting } \\
\text { sites/plant }\end{array}$} \\
\hline & & & 2016 & 2017 & 2016 & 2017 & 2016 & 2017 & 2016 & 2017 \\
\hline \multirow{5}{*}{$\begin{array}{c}\text { Population } \\
\text { density } \\
\text { through } \\
\text { plant } \\
\text { distribution }\end{array}$} & \multicolumn{2}{|r|}{$\mathbf{A}$} & 134.03 & 140.65 & 16.95 & 18.05 & 73.25 & 75.00 & 19.85 & 22.23 \\
\hline & \multicolumn{2}{|r|}{ B } & 131.63 & 138.15 & 17.63 & 19.18 & 71.63 & 74.00 & 22.50 & 24.58 \\
\hline & \multicolumn{2}{|r|}{ C } & 126.45 & 132.80 & 18.65 & 19.60 & 69.81 & 69.81 & 34.18 & 35.93 \\
\hline & \multicolumn{2}{|r|}{ D } & 123.08 & 129.33 & 19.18 & 20.25 & 68.38 & 69.00 & 36.23 & 39.10 \\
\hline & \multicolumn{2}{|r|}{$\mathbf{E}$} & 129.10 & 135.55 & 17.93 & 19.38 & 70.31 & 70.69 & 29.23 & 29.60 \\
\hline \multicolumn{3}{|c|}{ L.S.D. at 5\% } & 2.11 & 2.39 & 0.93 & 0.82 & 0.98 & 1.05 & 1.73 & 1.67 \\
\hline \multirow{4}{*}{$\begin{array}{c}\text { Nitrogen } \\
\text { fertilizer } \\
\text { level } \\
\text { (kg N/fed) }\end{array}$} & \multicolumn{2}{|r|}{30} & 123.90 & 130.86 & 16.52 & 17.92 & 68.50 & 69.55 & 24.32 & 26.52 \\
\hline & \multicolumn{2}{|r|}{45} & 128.12 & 134.62 & 17.82 & 18.96 & 70.20 & 71.45 & 27.72 & 30.02 \\
\hline & \multicolumn{2}{|r|}{60} & 130.78 & 137.08 & 18.60 & 19.76 & 71.60 & 72.50 & 30.04 & 31.86 \\
\hline & \multicolumn{2}{|r|}{75} & 132.62 & 138.62 & 19.32 & 20.52 & 72.40 & 73.30 & 31.50 & 32.74 \\
\hline \multicolumn{3}{|c|}{ L.S.D. at 5\% } & 1.79 & 1.23 & 0.75 & 0.78 & 0.91 & 0.85 & 1.65 & 1.23 \\
\hline \multirow{20}{*}{$\begin{array}{c}\text { Interaction } \\
\text { effect } \\
\text { between } \\
\text { population } \\
\text { densities } \\
\text { through } \\
\text { plant } \\
\text { distributions } \\
\text { and nitrogen } \\
\text { fertilizer } \\
\text { levels }\end{array}$} & \multirow{4}{*}{$\mathbf{A}$} & 30 & 127.90 & 135.00 & 15.60 & 16.90 & 71.00 & 72.75 & 15.10 & 17.90 \\
\hline & & 45 & 133.10 & 139.80 & 16.60 & 17.80 & 72.75 & 74.75 & 19.30 & 22.10 \\
\hline & & 60 & 136.50 & 143.00 & 17.50 & 18.40 & 74.25 & 75.75 & 21.80 & 24.30 \\
\hline & & 75 & 138.60 & 144.80 & 18.10 & 19.10 & 75.00 & 76.75 & 23.20 & 24.60 \\
\hline & \multirow{4}{*}{ B } & 30 & 126.20 & 133.20 & 15.90 & 17.70 & 69.75 & 71.25 & 18.30 & 20.80 \\
\hline & & 45 & 130.90 & 137.50 & 17.60 & 18.80 & 71.25 & 73.50 & 22.10 & 24.30 \\
\hline & & 60 & 133.80 & 140.20 & 18.10 & 19.70 & 72.50 & 75.00 & 24.30 & 26.50 \\
\hline & & 75 & 135.60 & 141.70 & 18.90 & 20.50 & 73.00 & 76.25 & 25.30 & 26.70 \\
\hline & \multirow{4}{*}{ C } & 30 & 121.90 & 128.80 & 16.90 & 18.30 & 67.50 & 68.25 & 29.50 & 31.90 \\
\hline & & 45 & 125.80 & 132.20 & 18.30 & 19.20 & 69.50 & 69.75 & 34.00 & 35.80 \\
\hline & & 60 & 128.20 & 134.40 & 19.40 & 20.10 & 70.75 & 70.25 & 35.80 & 37.40 \\
\hline & & 75 & 129.90 & 135.80 & 20.00 & 20.80 & 71.50 & 71.00 & 37.40 & 38.60 \\
\hline & \multirow{4}{*}{ D } & 30 & 119.20 & 126.00 & 17.70 & 18.80 & 66.25 & 67.00 & 32.90 & 35.50 \\
\hline & & 45 & 122.40 & 128.70 & 19.00 & 19.90 & 67.75 & 68.75 & 35.10 & 38.60 \\
\hline & & 60 & 124.50 & 130.60 & 19.70 & 20.70 & 69.25 & 69.75 & 37.60 & 40.50 \\
\hline & & 75 & 126.20 & 132.00 & 20.30 & 21.60 & 70.25 & 70.50 & 39.30 & 41.80 \\
\hline & \multirow{4}{*}{$\mathbf{E}$} & 30 & 124.30 & 131.30 & 16.50 & 17.90 & 68.00 & 68.50 & 25.80 & 26.50 \\
\hline & & 45 & 128.40 & 134.90 & 17.60 & 19.10 & 69.75 & 70.50 & 28.10 & 29.30 \\
\hline & & 60 & 130.90 & 137.20 & 18.30 & 19.90 & 71.25 & 71.75 & 30.70 & 30.60 \\
\hline & & 75 & 132.80 & 138.80 & 19.30 & 20.60 & 72.25 & 72.00 & 32.30 & 32.00 \\
\hline & & & 4.00 & 2.75 & 1.68 & 1.74 & 2.03 & 1.90 & 3.69 & 2.75 \\
\hline
\end{tabular}

$\mathrm{A}=64615$ plants/fed from $10 \mathrm{~cm}$ between hills with leaving single plant/hill.

$\mathrm{B}=64615$ plants/fed from $20 \mathrm{~cm}$ between hills with leaving double plants/hill.

$\mathrm{C}=43076$ plants $/$ fed from $15 \mathrm{~cm}$ between hills with leaving single plant/hill.

$\mathrm{D}=43076$ plants/fed from $30 \mathrm{~cm}$ between hills with leaving double plants/hill.

$\mathrm{E}=51692$ plants/fed from $25 \mathrm{~cm}$ between hills with leaving double plants/hill. 
Table 3. Effect of population densities through plant distributions, nitrogen fertilizer levels and their interaction on No. of open bolls/plant, boll weight, seed index and lint \% of cotton during 2016 and 2017 seasons.

\begin{tabular}{|c|c|c|c|c|c|c|c|c|c|c|}
\hline \multirow{2}{*}{ Treatment } & \multirow{2}{*}{\multicolumn{2}{|c|}{$\begin{array}{c}\text { Trait } \\
\text { Season }\end{array}$}} & \multicolumn{2}{|c|}{$\begin{array}{l}\text { No. of open } \\
\text { bolls/plant }\end{array}$} & \multicolumn{2}{|c|}{ Boll weight (g) } & \multicolumn{2}{|c|}{ Seed index (g) } & \multicolumn{2}{|c|}{ Lint \% } \\
\hline & & & 2016 & 2017 & 2016 & 2017 & 2016 & 2017 & 2016 & 2017 \\
\hline \multirow{5}{*}{$\begin{array}{c}\text { Population } \\
\text { density } \\
\text { through } \\
\text { plant } \\
\text { distribution }\end{array}$} & \multicolumn{2}{|r|}{$\mathbf{A}$} & 8.65 & 9.13 & 2.125 & 2.143 & 7.880 & 8.255 & 39.70 & 40.76 \\
\hline & \multicolumn{2}{|r|}{ B } & 9.60 & 9.70 & 2.208 & 2.163 & 8.048 & 8.455 & 38.98 & 40.18 \\
\hline & \multicolumn{2}{|r|}{$\mathbf{C}$} & 13.43 & 14.25 & 2.423 & 2.423 & 8.513 & 8.715 & 38.45 & 38.34 \\
\hline & \multicolumn{2}{|r|}{ D } & 14.13 & 14.68 & 2.588 & 2.503 & 8.718 & 8.950 & 38.28 & 38.05 \\
\hline & \multicolumn{2}{|r|}{$\mathbf{E}$} & 12.28 & 13.23 & 2.508 & 2.358 & 8.420 & 8.595 & 38.51 & 38.48 \\
\hline \multicolumn{3}{|c|}{ L.S.D. at 5\% } & 0.66 & 0.67 & 0.098 & 0.113 & 0.176 & 0.199 & 0.37 & 0.42 \\
\hline \multirow{4}{*}{$\begin{array}{c}\text { Nitrogen } \\
\text { fertilizer } \\
\text { level } \\
\text { (kg N/fed) }\end{array}$} & \multicolumn{2}{|r|}{30} & 10.08 & 11.26 & 2.260 & 2.158 & 7.594 & 7.922 & 39.32 & 40.21 \\
\hline & \multicolumn{2}{|r|}{45} & 11.70 & 12.24 & 2.352 & 2.340 & 8.362 & 8.552 & 38.81 & 39.15 \\
\hline & \multicolumn{2}{|r|}{60} & 12.26 & 12.58 & 2.412 & 2.366 & 8.588 & 8.874 & 38.55 & 38.90 \\
\hline & \multicolumn{2}{|r|}{75} & 12.42 & 12.70 & 2.456 & 2.406 & 8.718 & 9.028 & 38.46 & 38.39 \\
\hline \multicolumn{3}{|c|}{ L.S.D. at $5 \%$} & 0.33 & 0.21 & 0.051 & 0.055 & 0.162 & 0.187 & 0.23 & 0.19 \\
\hline \multirow{20}{*}{$\begin{array}{c}\text { Interaction } \\
\text { effect } \\
\text { between } \\
\text { population } \\
\text { densities } \\
\text { through } \\
\text { plant } \\
\text { distributions } \\
\text { and nitrogen } \\
\text { fertilizer } \\
\text { levels }\end{array}$} & \multirow{4}{*}{$\mathbf{A}$} & 30 & 7.30 & 8.40 & 2.020 & 1.940 & 7.210 & 7.330 & 40.25 & 41.52 \\
\hline & & 45 & 8.90 & 9.10 & 2.110 & 2.180 & 7.840 & 8.290 & 39.72 & 40.84 \\
\hline & & 60 & 9.10 & 9.40 & 2.150 & 2.210 & 8.150 & 8.670 & 39.45 & 40.56 \\
\hline & & 75 & 9.30 & 9.60 & 2.220 & 2.240 & 8.320 & 8.730 & 39.38 & 40.12 \\
\hline & \multirow{4}{*}{ B } & 30 & 8.30 & 8.90 & 2.140 & 1.970 & 7.350 & 7.510 & 39.45 & 41.01 \\
\hline & & 45 & 9.80 & 9.80 & 2.190 & 2.170 & 8.020 & 8.490 & 39.04 & 40.33 \\
\hline & & 60 & 10.10 & 10.00 & 2.220 & 2.220 & 8.330 & 8.830 & 38.76 & 40.10 \\
\hline & & 75 & 10.20 & 10.10 & 2.280 & 2.290 & 8.490 & 8.990 & 38.66 & 39.29 \\
\hline & \multirow{4}{*}{$\mathbf{C}$} & 30 & 11.70 & 13.00 & 2.380 & 2.260 & 7.810 & 8.210 & 39.02 & 39.65 \\
\hline & & 45 & 13.30 & 14.20 & 2.410 & 2.440 & 8.620 & 8.650 & 38.46 & 38.15 \\
\hline & & 60 & 14.30 & 14.80 & 2.430 & 2.480 & 8.740 & 8.890 & 38.19 & 37.98 \\
\hline & & 75 & 14.40 & 15.00 & 2.470 & 2.510 & 8.880 & 9.110 & 38.12 & 37.58 \\
\hline & \multirow{4}{*}{ D } & 30 & 12.20 & 13.50 & 2.400 & 2.430 & 7.930 & 8.570 & 38.75 & 39.12 \\
\hline & & 45 & 14.10 & 14.70 & 2.560 & 2.510 & 8.760 & 8.790 & 38.26 & 38.04 \\
\hline & & 60 & 15.00 & 15.20 & 2.680 & 2.520 & 9.030 & 9.150 & 38.11 & 37.76 \\
\hline & & 75 & 15.20 & 15.30 & 2.710 & 2.550 & 9.150 & 9.290 & 38.01 & 37.27 \\
\hline & \multirow{4}{*}{$\mathbf{E}$} & 30 & 10.90 & 12.50 & 2.360 & 2.190 & 7.670 & 7.990 & 39.11 & 39.73 \\
\hline & & 45 & 12.40 & 13.40 & 2.490 & 2.400 & 8.570 & 8.540 & 38.55 & 38.37 \\
\hline & & 60 & 12.80 & 13.50 & 2.580 & 2.400 & 8.690 & 8.830 & 38.23 & 38.11 \\
\hline & & 75 & 13.00 & 13.50 & 2.600 & 2.440 & 8.750 & 9.020 & 38.14 & 37.69 \\
\hline & & & 0.74 & 0.47 & 0.114 & 0.123 & N.S. & N.S. & N.S. & N.S. \\
\hline
\end{tabular}

$\mathrm{A}=64615$ plants/fed from $10 \mathrm{~cm}$ between hills with leaving single plant/hill.

$\mathrm{B}=64615$ plants/fed from $20 \mathrm{~cm}$ between hills with leaving double plants/hill.

$\mathrm{C}=43076$ plants/fed from $15 \mathrm{~cm}$ between hills with leaving single plant/hill.

$\mathrm{D}=43076$ plants $/ \mathrm{fed}$ from $30 \mathrm{~cm}$ between hills with leaving double plants/hill.

$\mathrm{E}=51692$ plants/fed from $25 \mathrm{~cm}$ between hills with leaving double plants/hill. 
Table 4. Effect of population densities through plant distributions, nitrogen fertilizer levels and their interaction on plant losses $\%$, seed cotton yield/plant, seed cotton yield/fed and lint cotton yield/fed of cotton during 2016 and 2017 seasons.

\begin{tabular}{|c|c|c|c|c|c|c|c|c|c|c|}
\hline \multirow{2}{*}{ Treatment } & \multirow{2}{*}{\multicolumn{2}{|c|}{$\begin{array}{c}\text { Trait } \\
\text { Season }\end{array}$}} & \multicolumn{2}{|c|}{ Plant losses \% } & \multicolumn{2}{|c|}{$\begin{array}{c}\text { Seed cotton } \\
\text { yield/plant }(g)\end{array}$} & \multicolumn{2}{|c|}{$\begin{array}{c}\text { Seed cotton } \\
\text { yield/fed (kentar) }\end{array}$} & \multicolumn{2}{|c|}{$\begin{array}{c}\text { Lint cotton } \\
\text { yield/fed (kentar) }\end{array}$} \\
\hline & & & 2016 & 2017 & 2016 & 2017 & 2016 & 2017 & 2016 & 2017 \\
\hline \multirow{5}{*}{$\begin{array}{c}\text { Population } \\
\text { density } \\
\text { through } \\
\text { plant } \\
\text { distribution }\end{array}$} & \multicolumn{2}{|r|}{$\mathbf{A}$} & 7.08 & 5.86 & 18.43 & 19.60 & 6.818 & 7.270 & 8.515 & 9.320 \\
\hline & \multicolumn{2}{|r|}{ B } & 4.29 & 3.78 & 21.23 & 21.03 & 7.913 & 7.778 & 9.705 & 9.828 \\
\hline & \multicolumn{2}{|r|}{ C } & 6.25 & 4.42 & 32.55 & 34.60 & 8.408 & 8.778 & 10.173 & 10.578 \\
\hline & \multicolumn{2}{|r|}{ D } & 3.44 & 2.90 & 36.69 & 36.76 & 9.468 & 9.338 & 11.403 & 11.173 \\
\hline & \multicolumn{2}{|r|}{$\mathbf{E}$} & 4.06 & 3.65 & 30.86 & 31.22 & 9.753 & 9.630 & 11.815 & 11.650 \\
\hline \multicolumn{3}{|c|}{ L.S.D. at 5\% } & 0.52 & 0.46 & 1.71 & 2.02 & 0.476 & 0.395 & 0.563 & 0.498 \\
\hline \multirow{4}{*}{$\begin{array}{c}\text { Nitrogen } \\
\text { fertilizer } \\
\text { level } \\
(\mathrm{kg} \mathrm{N} / \mathrm{fed})\end{array}$} & \multicolumn{2}{|r|}{30} & 5.07 & 4.30 & 23.07 & 24.68 & 6.670 & 7.048 & 8.248 & 8.902 \\
\hline & \multicolumn{2}{|r|}{45} & 5.14 & 3.99 & 27.85 & 28.96 & 8.294 & 8.546 & 10.128 & 10.506 \\
\hline & \multicolumn{2}{|r|}{60} & 4.81 & 4.00 & 29.99 & 30.08 & 9.258 & 9.212 & 11.224 & 11.258 \\
\hline & \multicolumn{2}{|r|}{75} & 5.07 & 4.20 & 30.89 & 30.85 & 9.664 & 9.428 & 11.688 & 11.372 \\
\hline \multicolumn{3}{|c|}{ L.S.D. at $5 \%$} & N.S. & N.S. & 0.91 & 0.78 & 0.461 & 0.318 & 0.503 & 0.415 \\
\hline \multirow{20}{*}{$\begin{array}{c}\text { Interaction } \\
\text { effect } \\
\text { between } \\
\text { population } \\
\text { densities } \\
\text { through } \\
\text { plant } \\
\text { distributions } \\
\text { and nitrogen } \\
\text { fertilizer } \\
\text { levels }\end{array}$} & \multirow{4}{*}{$\mathbf{A}$} & 30 & 7.02 & 5.95 & 14.75 & 16.30 & 5.230 & 5.790 & 6.630 & 7.570 \\
\hline & & 45 & 7.14 & 5.71 & 18.78 & 19.84 & 6.870 & 7.250 & 8.600 & 9.330 \\
\hline & & 60 & 6.90 & 5.95 & 19.57 & 20.77 & 7.430 & 7.890 & 9.230 & 10.080 \\
\hline & & 75 & 7.26 & 5.83 & 20.65 & 21.50 & 7.740 & 8.150 & 9.600 & 10.300 \\
\hline & \multirow{4}{*}{ B } & 30 & 4.29 & 3.81 & 17.76 & 17.53 & 6.310 & 6.230 & 7.840 & 8.050 \\
\hline & & 45 & 4.40 & 3.69 & 21.46 & 21.27 & 7.820 & 7.780 & 9.620 & 9.880 \\
\hline & & 60 & 4.17 & 3.69 & 22.42 & 22.20 & 8.510 & 8.430 & 10.390 & 10.650 \\
\hline & & 75 & 4.29 & 3.93 & 23.26 & 23.13 & 9.010 & 8.670 & 10.970 & 10.730 \\
\hline & \multirow{4}{*}{$\mathbf{C}$} & 30 & 6.07 & 4.82 & 27.85 & 29.38 & 6.850 & 7.150 & 8.420 & 8.930 \\
\hline & & 45 & 6.61 & 4.29 & 32.05 & 34.65 & 8.110 & 8.670 & 9.830 & 10.420 \\
\hline & & 60 & 5.89 & 3.93 & 34.75 & 36.70 & 9.150 & 9.550 & 11.010 & 11.430 \\
\hline & & 75 & 6.43 & 4.64 & 35.57 & 37.65 & 9.520 & 9.740 & 11.430 & 11.530 \\
\hline & \multirow{4}{*}{ D } & 30 & 3.93 & 3.21 & 29.28 & 32.81 & 7.210 & 7.980 & 8.800 & 9.830 \\
\hline & & 45 & 3.39 & 2.68 & 36.10 & 36.90 & 9.120 & 9.250 & 10.990 & 11.080 \\
\hline & & 60 & 3.21 & 2.86 & 40.20 & 38.30 & 10.570 & 9.970 & 12.690 & 11.860 \\
\hline & & 75 & 3.21 & 2.86 & 41.19 & 39.02 & 10.970 & 10.150 & 13.130 & 11.920 \\
\hline & \multirow{4}{*}{$\mathbf{E}$} & 30 & 4.02 & 3.72 & 25.72 & 27.38 & 7.750 & 8.090 & 9.550 & 10.130 \\
\hline & & 45 & 4.17 & 3.57 & 30.88 & 32.16 & 9.550 & 9.780 & 11.600 & 11.820 \\
\hline & & 60 & 3.87 & 3.57 & 33.02 & 32.40 & 10.630 & 10.220 & 12.800 & 12.270 \\
\hline & & \multirow[t]{2}{*}{75} & 4.17 & 3.72 & 33.80 & 32.94 & 11.080 & 10.430 & 13.310 & 12.380 \\
\hline & & & N.S. & N.S. & 2.03 & 1.74 & 1.031 & 0.711 & 1.125 & 0.928 \\
\hline
\end{tabular}

$\mathrm{A}=64615$ plants/fed from $10 \mathrm{~cm}$ between hills with leaving single plant/hill.

$\mathrm{B}=64615$ plants $/$ fed from $20 \mathrm{~cm}$ between hills with leaving double plants/hill.

$\mathrm{C}=43076$ plants $/$ fed from $15 \mathrm{~cm}$ between hills with leaving single plant/hill.

$\mathrm{D}=43076$ plants/fed from $30 \mathrm{~cm}$ between hills with leaving double plants/hill.

$\mathrm{E}=51692$ plants/fed from $25 \mathrm{~cm}$ between hills with leaving double plants/hill. 
Table 5. Effect of population densities through plant distributions, nitrogen fertilizer levels and their interaction on fiber properties of cotton during 2016 and 2017 seasons.

\begin{tabular}{|c|c|c|c|c|c|c|c|c|c|c|c|c|}
\hline \multirow[t]{2}{*}{ Treatment } & \multirow{2}{*}{\multicolumn{2}{|c|}{$\begin{array}{c}\text { Trait } \\
\text { Season }\end{array}$}} & \multicolumn{2}{|c|}{$\begin{array}{c}\text { Upper half } \\
\text { mean length } \\
(\mathrm{mm})\end{array}$} & \multicolumn{2}{|c|}{$\begin{array}{l}\text { Uniformity } \\
\text { index } \%\end{array}$} & \multicolumn{2}{|c|}{ Strength (g/tex) } & \multicolumn{2}{|c|}{ Elongation \% } & \multicolumn{2}{|c|}{$\begin{array}{l}\text { Micronaire } \\
\text { reading }\end{array}$} \\
\hline & & & 2016 & 2017 & 2016 & 2017 & 2016 & 2017 & 2016 & 2017 & 2016 & 2017 \\
\hline \multirow{5}{*}{$\begin{array}{c}\text { Population } \\
\text { density } \\
\text { through } \\
\text { plant } \\
\text { distribution }\end{array}$} & & $\mathbf{A}$ & 29.30 & 29.78 & 80.83 & 80.61 & 37.72 & 36.00 & 7.22 & 7.12 & 3.765 & 3.822 \\
\hline & & B & 29.66 & 30.35 & 81.81 & 82.15 & 36.76 & 35.93 & 7.04 & 7.10 & 3.702 & 3.739 \\
\hline & & $\mathbf{C}$ & 30.41 & 30.93 & 83.55 & 83.69 & 38.95 & 37.90 & 7.46 & 7.49 & 3.888 & 3.895 \\
\hline & & D & 30.72 & 31.04 & 83.97 & 83.89 & 38.79 & 37.56 & 7.43 & 7.43 & 3.840 & 3.881 \\
\hline & & $\mathbf{E}$ & 30.14 & 30.70 & 82.90 & 83.13 & 38.04 & 37.37 & 7.29 & 7.39 & 3.835 & 3.867 \\
\hline \multicolumn{3}{|l|}{ L.S.D. at $5 \%$} & N.S. & 0.67 & 0.89 & 0.94 & 0.88 & 0.75 & N.S. & N.S. & 0.072 & 0.067 \\
\hline \multirow{4}{*}{$\begin{array}{c}\text { Nitrogen } \\
\text { fertilizer } \\
\text { level } \\
(\mathbf{k g ~ N / f e d})\end{array}$} & & 30 & 29.29 & 29.88 & 81.55 & 81.67 & 37.70 & 36.66 & 7.54 & 7.48 & 3.891 & 3.940 \\
\hline & & 45 & 30.03 & 30.50 & 82.38 & 82.36 & 38.41 & 37.23 & 7.39 & 7.45 & 3.853 & 3.887 \\
\hline & & 60 & 30.29 & 30.83 & 83.06 & 83.21 & 38.43 & 37.25 & 7.25 & 7.23 & 3.810 & 3.823 \\
\hline & & 75 & 30.57 & 31.03 & 83.46 & 83.53 & 37.65 & 36.66 & 6.97 & 7.05 & 3.670 & 3.712 \\
\hline \multicolumn{3}{|l|}{ L.S.D. at $5 \%$} & N.S. & N.S. & 0.76 & 0.83 & N.S. & N.S. & N.S. & N.S. & 0.069 & 0.063 \\
\hline \multirow{20}{*}{$\begin{array}{c}\text { Interaction } \\
\text { effect } \\
\text { between } \\
\text { population } \\
\text { densities } \\
\text { through plant } \\
\text { distributions } \\
\text { and nitrogen } \\
\text { fertilizer } \\
\text { levels }\end{array}$} & \multirow{4}{*}{ A } & 30 & 28.55 & 29.15 & 79.51 & 79.71 & 36.77 & 35.76 & 7.35 & 7.30 & 3.887 & 3.945 \\
\hline & & 45 & 29.43 & 29.88 & 80.93 & 80.68 & 38.58 & 36.18 & 7.42 & 7.24 & 3.818 & 3.875 \\
\hline & & 60 & 29.54 & 29.99 & 81.24 & 80.97 & 38.25 & 36.25 & 7.22 & 7.04 & 3.779 & 3.836 \\
\hline & & 75 & 29.69 & 30.11 & 81.65 & 81.06 & 37.26 & 35.81 & 6.90 & 6.89 & 3.576 & 3.630 \\
\hline & \multirow{4}{*}{$\mathbf{B}$} & 30 & 29.01 & 29.67 & 80.78 & 81.11 & 36.25 & 35.61 & 7.25 & 7.27 & 3.825 & 3.863 \\
\hline & & 45 & 29.62 & 30.21 & 81.46 & 81.57 & 37.15 & 36.09 & 7.14 & 7.22 & 3.797 & $\mathbf{3 . 8 3 5}$ \\
\hline & & 60 & 29.89 & 30.65 & 82.20 & 82.76 & 37.25 & 36.23 & 7.03 & 7.03 & 3.701 & 3.738 \\
\hline & & 75 & 30.11 & 30.88 & 82.80 & 83.17 & 36.37 & 35.77 & 6.74 & 6.88 & 3.485 & 3.520 \\
\hline & \multirow{4}{*}{$\mathbf{C}$} & 30 & 29.64 & 30.21 & 82.51 & 82.57 & 38.85 & 37.62 & 7.77 & 7.68 & 3.933 & 3.975 \\
\hline & & 45 & 30.34 & 30.83 & 83.44 & 83.24 & 39.11 & 38.26 & 7.52 & 7.65 & 3.899 & 3.918 \\
\hline & & 60 & 30.65 & 31.25 & 84.01 & 84.38 & 39.25 & 38.14 & 7.41 & 7.41 & 3.911 & 3.859 \\
\hline & & 75 & 30.99 & 31.43 & 84.22 & 84.56 & 38.57 & 37.56 & 7.14 & 7.22 & 3.807 & 3.826 \\
\hline & \multirow{4}{*}{ D } & 30 & 29.79 & 30.25 & 82.92 & 82.68 & 38.66 & 37.29 & 7.73 & 7.61 & 3.911 & 3.962 \\
\hline & & 45 & 30.76 & 30.96 & 83.59 & 83.59 & 38.98 & 37.88 & 7.50 & 7.58 & 3.875 & 3.910 \\
\hline & & 60 & 31.05 & 31.37 & 84.39 & 84.53 & 39.13 & 37.89 & 7.38 & 7.36 & 3.800 & 3.843 \\
\hline & & 75 & 31.26 & 31.57 & 84.97 & 84.76 & 38.37 & 37.19 & 7.11 & 7.15 & 3.775 & 3.809 \\
\hline & \multirow{5}{*}{$\mathbf{E}$} & 30 & 29.46 & 30.10 & 82.02 & 82.27 & 37.95 & 37.02 & 7.59 & 7.56 & 3.901 & 3.953 \\
\hline & & 45 & 29.99 & 30.64 & 82.47 & 82.73 & 38.25 & 37.72 & 7.36 & 7.54 & 3.876 & 3.899 \\
\hline & & 60 & 30.34 & 30.89 & 83.44 & 83.40 & 38.29 & 37.76 & 7.22 & 7.33 & 3.857 & 3.839 \\
\hline & & 75 & 30.78 & 31.15 & 83.65 & 84.11 & 37.67 & 36.98 & 6.98 & 7.11 & 3.705 & 3.777 \\
\hline & & & N.S. & N.S. & N.S. & N.S. & N.S. & N.S. & N.S. & N.S. & N.S. & N.S. \\
\hline
\end{tabular}




\section{References}

A. S. T. M. 1986. American Society for Testing and Materials. D-4605., 1(7), Easton, MD, USA.

Abd El-Aal, A. S. A. 2014. Effect of some plant densities patterns and nitrogen fertilizer levels on cotton yield, its components and fiber properties for hybrid cotton 10229 x Giza 86 under early and late sowing. J. Plant Production, Mansoura Univ., 5 (7): 1239-1258.

Ali, A., M. Tahir, M. Ayub, I. Ali, A. Wasaya, and F. Khalid. 2009. Studies on the effect of plant spacing on the yield of recently approved varieties of cotton. Pak. j. life Soc. Sci., 7 (1):2530

Ali, H., M. N. Afzal, F. Ahmad, S. Ahmad, M. Akhtar, and R. Atif. 2011. Effect of sowing dates, plant spacing and nitrogen application on growth and productivity on cotton crop. Int. J Sci. \& Eng. Res., 2 (9): 1-6.

Alitabar, R. A., R. Salimbeck, O. Alishah, and S. A. Andarkhor. 2012. Interactive effects of nitrogen and row spacing on growth and yield of cotton varieties. Int. J. Biol., 4 (3): 124-129.

Alubaidi, M. A., M. A. Al-Naqeeb, and H. K. Saleh. 2016. Response of cotton to nitrogen fertilizer and spacing between hills. Iraqi J. Agric. Sci., 47 (6): 1562-1567.

Black, C.A., and D. D. Evans. 1965. Methods of Soil Analysis. Amer. Soc. of Agron., Inc. Pub. Madison, Wisconsin, USA.

Darawsheh, M. K., D. Chachalis, G. Aivalakis, and E. M. Khah. 2009. Cotton row spacing and plant density cropping systems. II. Effects on seed cotton yield, boll components and lint quality. J. Food, Agric. Env., 7 (3\&4): $262-265$.

Deshish, El-D. El-D. 2013. Suitable agricultural management practices for the new promising hybrid cotton [Giza 84 (Giza 70 x 51 B)] pima 62. J. Plant Production, Mansoura Univ., 4 (12): 1885-1896.

Deshish, El-D. El-D., S. A. F. Hamoda, and M. A. A. Ibrahim. 2015. Cotton response to planting distance and different surface irrigation systems in heavy soil at North Delta. Special Issue of J. Adv. Agric, Res. (Fac. Agric. Saba Basha). Alex. Cotton Conf. 25-26 march, 83-93.

Egyptian Cotton Gazette. 2017. Alcotexa. 149: 51.

El-Sayed, E. A., and M. El-Menshawi. 2005. Response of the promising hybrid cotton Giza 89 $\mathrm{X} 86$ to hill spacing and nitrogen fertilizer level. J. Agric. Res. Tanta Univ., 31 (1): 436-456.

El-Shahawy, M. I. M., and S. A. F. Hamoda. 2011. The proper agricultural management practices for the new promising hybrid cotton (Giza $77 \mathrm{x}$ Pima S6). J. Plant Production Mansoura Univ., 2 (11): 1551-1561.

Gomez, K. A., and A. A. Gomez. 1984. Statistical Procedures for Agricultural Research. 2nd, (ed). John Wiley and Sons, NY, U.S.A.
Hamed, F. S. 2013. Response of cotton (Giza 90 cultivar) to nitrogen level and biofertilization with rizobacterein. Egypt. J. Appl. Sci., 28 (3): 157-168.

Hamed, F. S., A. S. Abo El-Hamd, M. M. Ibrahim, and A. E. M. El-Sayed. 2012. Effect of some cultural practices on growth, flowering, earliness characters and yield of cotton plant Giza 90 (Gossypium barbadense, L.). Egypt. J. Agric. Res., 90 (4): 1649-1675.

Hamoda, S. A. F., M. A. A. Ibrahim, and M. A.A. Emara. 2014. Effect of planting patterns and fertilization under two planting dates on growth, yield and quality of new hybrid cotton [Giza 84 (Giza 75 x 5844)] Giza 80. J. Egypt. J. Agric. Res., 92 (1): 125-137.

Khan, A., U. Najeeb, L. Wang, D. K. Y. Tan, G. Yang, F. Munsif, S. Ali, and A. Hafeez. 2017. Planting density and sowing date strongly influence growth and lint yield of cotton crops. Field Crops Res., 209: 129-135.

Khan, M. B.; N. Hussain, and M. Asif. 2001. Growth and yield of cotton as influenced by various nitrogen levels and plant population. Int. J. Agri. Biol., 3 (1): 5-7.

Madani, A., and M. Oveysi. 2015. Fiber quality and yield response of cotton to nitrogen supply. Int. Conf. Chem. Food \& Env. Eng. 11-12 Jan., 3339.

Madavi, B., P. L. Rani, G. Sreenivas, and K. Surekha. 2017. Effect of high density planting and weed management practices on weed dry matter, weed indices and yield of Bt cotton. Int. J. Pure App. Biosci., 5 (4): 1945-1950.

Mccarty, J. C., J. N. Jenkins, R. W. Hayes, and M. J. Wubben. 2017. Effects of plant density on boll retention and yield of cotton in the MidSouth. American J. Plant Sci., 8: 891-906.

Michigan State University. 1983. MSTAT-C: Micro-computer Statistical Program, Version 2. Michigan State University, East Lansing.

Mubarak, I., and M. Janat. 2018. Response of new cotton variety (Rassafa) to nitrogen fertilizer and partial root-zone drying drip irrigation. Open Agric. J., 12: 1-10.

Munir, M. K., M. Tahir, M. F. Saleem, and M. Yaseen. 2015. Growth, yield and earliness response of cotton to row spacing and nitrogen management. J. Anim. Plant Sci., 25 (3): 729: 738.

Nadeem, M. A., A. Ali, M. Tahir, M. Naeem, A. R. Chadhar, and S. Ahmad. 2010. Effect of nitrogen levels and plant spacing on growth and yield of cotton. Pak. j. life Soc. Sci., 8 (2): 121124.

Nagender, T., D. R. Reddy, P. L. Rani, G. Sreenivas, K. Surekha, A. Gupta, and P.D. Sreekanth. 2017. Response of nitrogen fertilization and plant densities on $\mathrm{Bt}$ and Non-Bt 
COTTON (Gossypium hirsutum, L.) hybrids. Int. J. Curr. Microbiol. App. Sci., 6 (9): 3199-3207.

Panhwar, R. B., A. Akbar, B. U. Panhwar, G. A. Panhwar, and F. Bai-li. 2018. Effects of plant spacing and nitrogen fertilizer levels on cotton yield and growth. Int. J. Sci, Envi. \&Tech., 7 (1): 313-324.

Ran, L. J., Z. Wen-Qing, Z. Zhi-Guo, D. He-Lin, Z. Xin-Hua, and M. Ya-Li. 2015. Effects of nitrogen levels and planting dates on yield, quality and photosynthate contents in the subtending leaves of cotton boll. J. Plant Nut. Fert., 21 (4): 951-961.
Shah, T., M. Kalsoom, K. Eifediye, and H. A. Khan. 2017. Yield and quality characters of cotton varieties response to different plant spacing. Middle East J. Agric. Res., 6 (1): 113118.

Siddiqui, M. H., F. C. Oad and U. A. Buriro. 2007. Plant spacing effects on growth, yield and lint of cotton. Asian J. Plant Sci., 6 (2): 415-418.

Singh, A. K., J. Kumar, R. Kumar, S. Kumar, and S. Kumar. 2017. Effect of spacing and nutrients management on growth, yield, yield attributes and quality characters in hirsutum cotton of central plain zone of U.P. India. Int. J. Curr. Microbiol. App. Sci., 6 (11): 5358-5366. 
تأثير الكثافة النباتية والسماد النيتروجيني على النمو ومكونات المحصول والمحصول وخصائص التيلة في القطن المصري (جيزة ه هو)

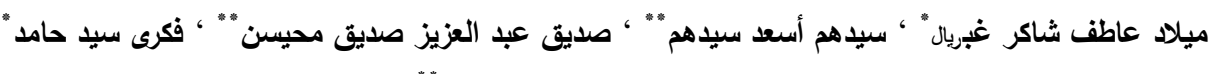

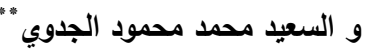

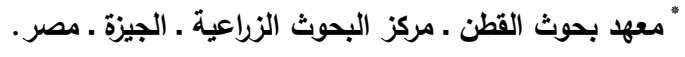

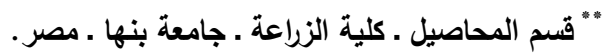

أقيمت تجربتان حقليتان بمزرعة محطة البحوث الزراعية بسدس - محافظة بني سويف- مركز البحوث الزراعية خلال موسمي الزراعة

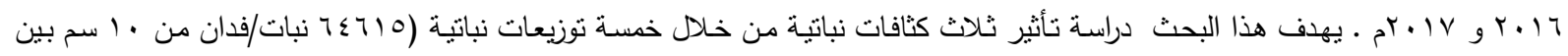

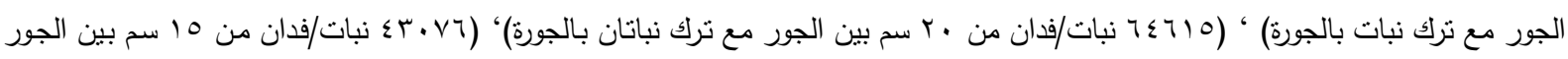

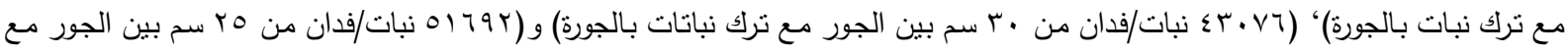

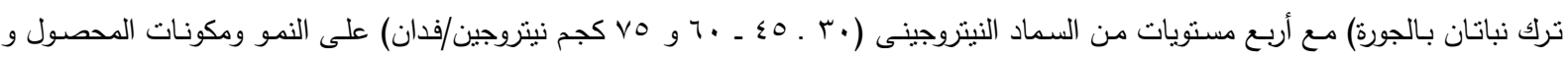

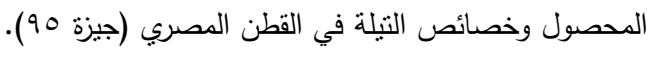
ويمكن تلخيص أهم النتائج فيما يلي :.

أثنارت النتائج أن الإختلافات بين الكثافات النباتية من خلال توزيع النباتات تحت الدراسة كانت معنوية في معظم صفات النات النمو والتزهير

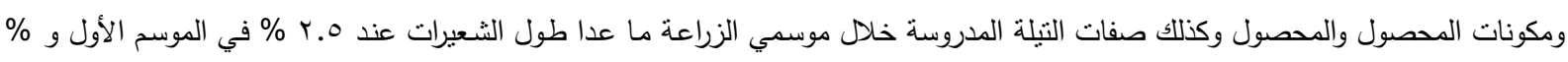

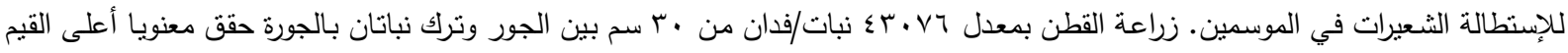

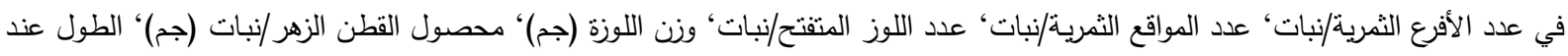

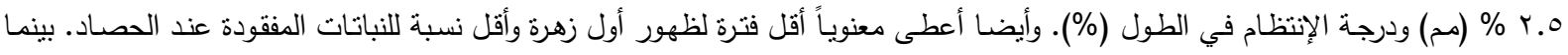

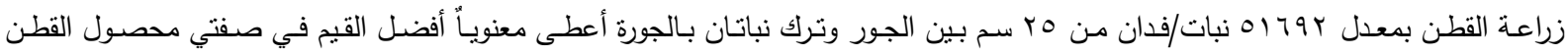

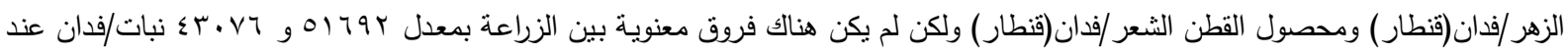

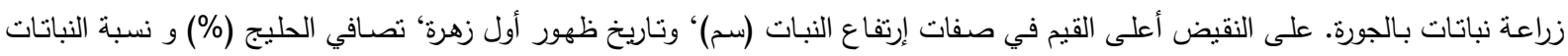

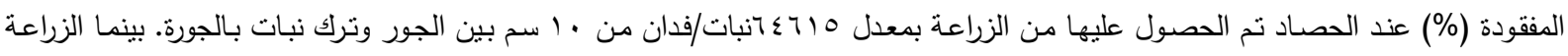

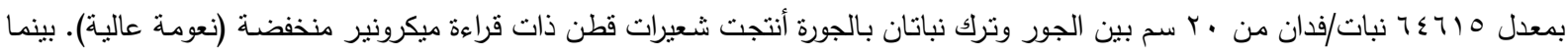

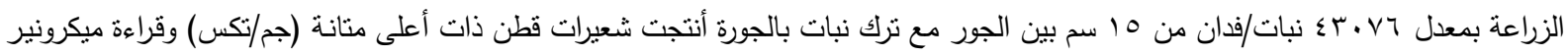
عالية.

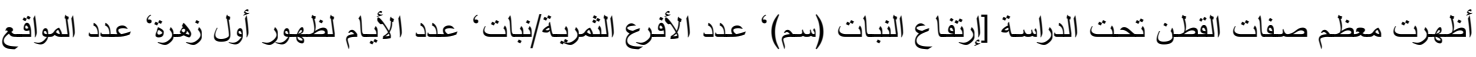

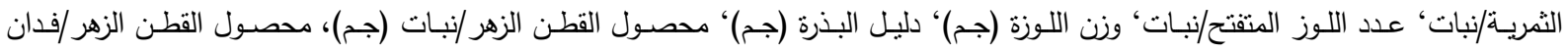

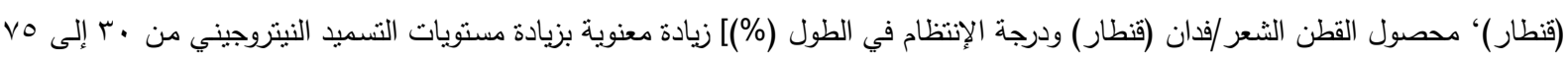

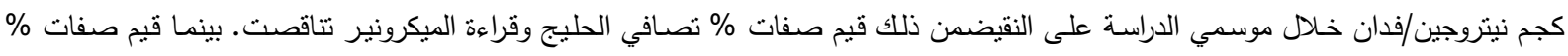

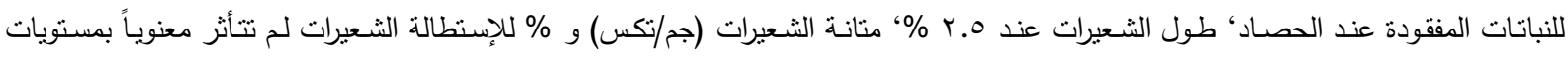

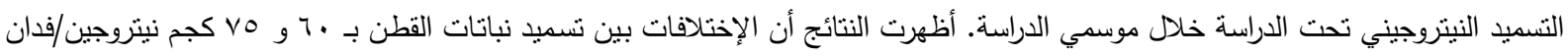
لم تكن معنوية في معظم القطن المدروسة.

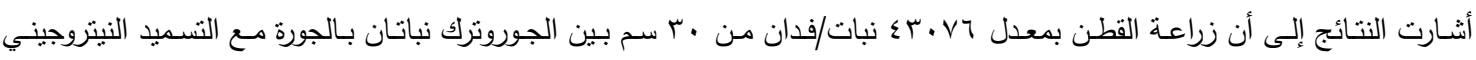

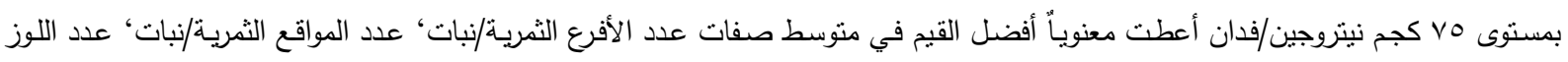

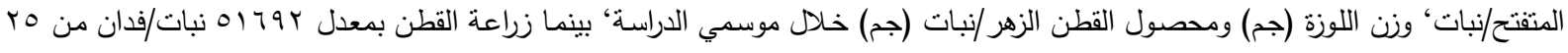

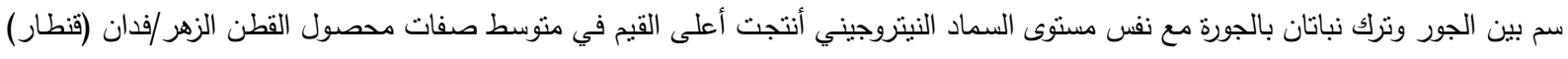

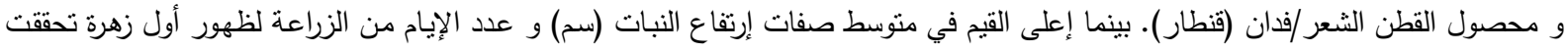

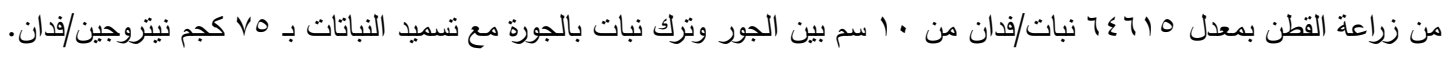

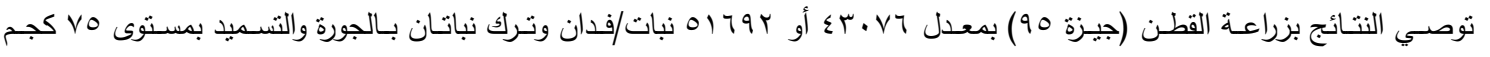

نيتروجين/فدان حيث زادت صفات النمو ومكونات المحصول والمحصول وخصائص بند التيلة . 